\title{
Land Use and Land Cover Change along River Lumi Riparian Ecosystem in Kenya: Implications on Local Livelihoods
}

\author{
Leila A. Ndalilo1,2*, Elias K. Maranga1, Bernard K. Kirui1 \\ ${ }^{1}$ Department of Natural Resources, Egerton University, Egerton, Kenya \\ ${ }^{2}$ Kenya Forestry Research Institute, Coast Eco-Region Research Programme, Malindi, Kenya \\ Email: *leylilo@yahoo.com
}

How to cite this paper: Ndalilo, L. A., Maranga, E. K., \& Kirui, B. K. (2021). Land Use and Land Cover Change along River Lumi Riparian Ecosystem in Kenya: Implications on Local Livelihoods. Open Journal of Forestry, 11, 206-221.

https://doi.org/10.4236/ojf.2021.113014

Received: March 17, 2021

Accepted: June 14, 2021

Published: June 17, 2021

Copyright $\odot 2021$ by author(s) and Scientific Research Publishing Inc. This work is licensed under the Creative Commons Attribution International License (CC BY 4.0).

http://creativecommons.org/licenses/by/4.0/

\begin{abstract}
Riparian forests minimize impacts of land degradation on stream ecosystems and provide direct and indirect benefits to people. However, these ecosystems are threatened by degradation and deforestation attributed to land use changes. River Lumi riparian ecosystem in Taita Taveta County in Kenya has experienced rapid and extensive land use changes over the past three decades in response to economic, institutional and demographic factors. There is growing concern of riparian degradation attributed to land use change with far reaching implications on local livelihoods. A study was conducted to examine the patterns of land use and land cover change along River Lumi riparian ecosystem between 1987 and 2019. The aim of the study was to ascertain the impacts of land use and land cover change on local livelihoods. Landsat images were used to assess land use and land cover change while socio-economic data was collected from 353 households in Njukini, Chala and Mboghoni located in the upper, middle and lower sections of River Lumi ecosystem respectively. Research evidence authenticated that the area under farmlands, settlement and water body increased by $20.5 \%, 112.1 \%$ and $2.3 \%$ respectively between 1987 and 2019 while area under forest patches, grazing land and riverine vegetation decreased by $52.7 \%, 3.0 \%$, and $36.6 \%$ respectively. The increase in population in surrounding areas coupled with encroachment of the riparian areas for crop farming and livestock grazing resulted to loss of riparian forest patches/ vegetation and associated biodiversity with negative implications on household livelihoods. The implication of these results is the need for land use regulations and management interventions at the County level to arrest further encroachment of River Lumi riparian ecosystem and consequent loss of biodiversity and livelihoods.
\end{abstract}




\section{Keywords}

Land Cover, Land Use, Livelihoods, River Lumi and Riparian Ecosystem

\section{Introduction}

Riparian forests regulate water and soil quality, minimize impacts of landscape disturbance on stream ecosystems (Rodriguez et al., 2011), and provide direct and indirect benefits to people (Wang et al., 2014). Despite their immense importance, riparian ecosystems are threatened by degradation and deforestation attributed to land use changes (Rodriguez et al., 2011). Agricultural intensification, deforestation and urbanization are the main land uses that have contributed immensely to tremendous changes in land cover on a global scale (DeFries et al., 2004). These activities are largely driven by the need to meet immediate human needs at the expense of environmental conservation resulting in decline in biodiversity through the loss, modification and fragmentation of habitats, degradation of soil and water quality; and overexploitation of native species (Odira et al., 2010; Mendez-Estrella et al., 2016). In developing countries, it has been observed that the conversion of land use and land cover into agricultural land and urban areas has resulted in various environmental consequences such as loss of ecosystem integrity, ecosystem imbalance and below optimum provision of ecosystem services (Kindu et al., 2015). Studies indicate that the period beginning 1990s to date has been characterized by a rapid increase in conversion of grassland, woodland and forests into croplands and pasture lands in the tropics (Houghton, 1994; Williams, 1994; Faye, 2016). This acceleration has spurred renewed concerns about the role of land use change in driving losses in biological diversity, soils fertility and water quality. Thus, the protection and management of watersheds have emerged as a local and national policy imperative throughout the developing world (Faye, 2016). The growing populations and mismanagement of complex, fragile and poorly understood riverine ecosystems continue to jeopardize the livelihoods of local populations as well as the prospects for environmental protection and conservation (World Bank, 1992; Foley et al., 2011).

In Africa, riparian areas continue to suffer degradation attributed to changes in land uses and cover, and poor land management practices (Foley et al., 2011; Halmy et al., 2015; Faye, 2016). In Sub-Sahara Africa, the intensive use of land for agricultural expansion by local communities to satisfy their basic needs is the most important driver of land use and land cover change (Nacoulma et al., 2011; Kadeba et al., 2015). Earlier studies on riparian ecosystems in Kenya (Mutie et al., 2006; Baldyga et al., 2007; Kathumo, 2011; Monene, 2017) have indicated that human population growth, overexploitation of resources and attendant poverty are leading causes of land use and land cover change along river basins. Moreover, forests, shrubland, grassland and water bodies have reduced at the expense of increase in agricultural land and urbanization. Thus, anthropogenic alterations of 
the natural landscape have caused significant effects on the physical, hydrological and ecological processes of riparian ecosystems (Chiwa, 2012; Faye, 2016).

The area around River Lumi has experienced rapid and extensive land use changes in the last three decades in response to economic, institutional and demographic factors (NEMA, 2009; Muli, 2014; Ngugi et al., 2015). There is growing concern regarding land degradation resulting from deforestation of the riparian forest and agricultural expansion leading to destruction of the delicate riparian ecosystem (Muli, 2014; Ngugi et al., 2015). Information is needed on the pattern of land use and land cover change to guide the development of strategies for sustainable management of River Lumi riparian ecosystem. This study examined the pattern of land use and land cover change along River Lumi riparian ecosystem between 1987 and 2019 and the resulting impacts on local livelihoods.

\section{Materials and Methods}

\subsection{Description of Study Area}

The study was undertaken in the riparian area along River Lumi, which originates from Mt. Kilimanjaro flowing North East wards to cross the border from Tanzania to Kenya and flows into Lake Jipe (Figure 1). River Lumi riparian ecosystem which covers an area of $590 \mathrm{~km}^{2}$ is situated in Taita Taveta County, approximately $200 \mathrm{Km}$ northwest of the coastal city of Mombasa in Kenya. The area experiences a dry semi-arid climate with a bi-modal rainfall pattern; the annual rainfall range between $300 \mathrm{~mm}$ to $1200 \mathrm{~mm}$ with a mean annual rainfall of $616 \mathrm{~mm}$. The altitude ranges from 1200 metres above sea level in the lowlands to 1800 metres above sea level in the highlands, while temperatures are fairly constant with a mean monthly maximum of approximately $32^{\circ} \mathrm{C}$ and mean monthly minimum of $17^{\circ} \mathrm{C}$ (Republic of Kenya, 2014). The main land uses along the riparian ecosystem are crop farming and livestock production (Muli, 2014).

\subsection{Assessment of Forest Cover Change}

Landsat 8 satellite images: Multispectral Scanner (MSS), Thematic Mapper (TM), and Enhanced Thematic Mapper (ETM), which have spectral resolution of $30 \mathrm{~m}$ were used to assess land use and land cover change. Landsat images were collected from four epochs: 1987; 2000; 2010; and 2019. Images were downloaded from the United States Geological Survey (USGS) website (https://glovis.usgs.gov/), and selected based on cloud cover: only those with less than $10 \%$ cloud cover were analyzed to give in-depth insights on the trends in land use and land cover change. Exposure time frames of 13 years between 1987 and 2000, 10 years from 2000 to 2010 and 9 years from 2010 to 2019 were used to examine the pattern of land use and land cover changes along River Lumi riparian ecosystem in the 32-year period between 1987 and 2019.

Landsat MSS images used had four spectral bands, spatial resolution of $60 \mathrm{~m}$ and a swath (scene size) of $165 \times 165 \mathrm{~m}$. Landsat TM images consisted of seven spectral bands, resolution of $30 \mathrm{~m}$ and swath of $185 \times 185 \mathrm{~m}$. Landsat ETM+ 


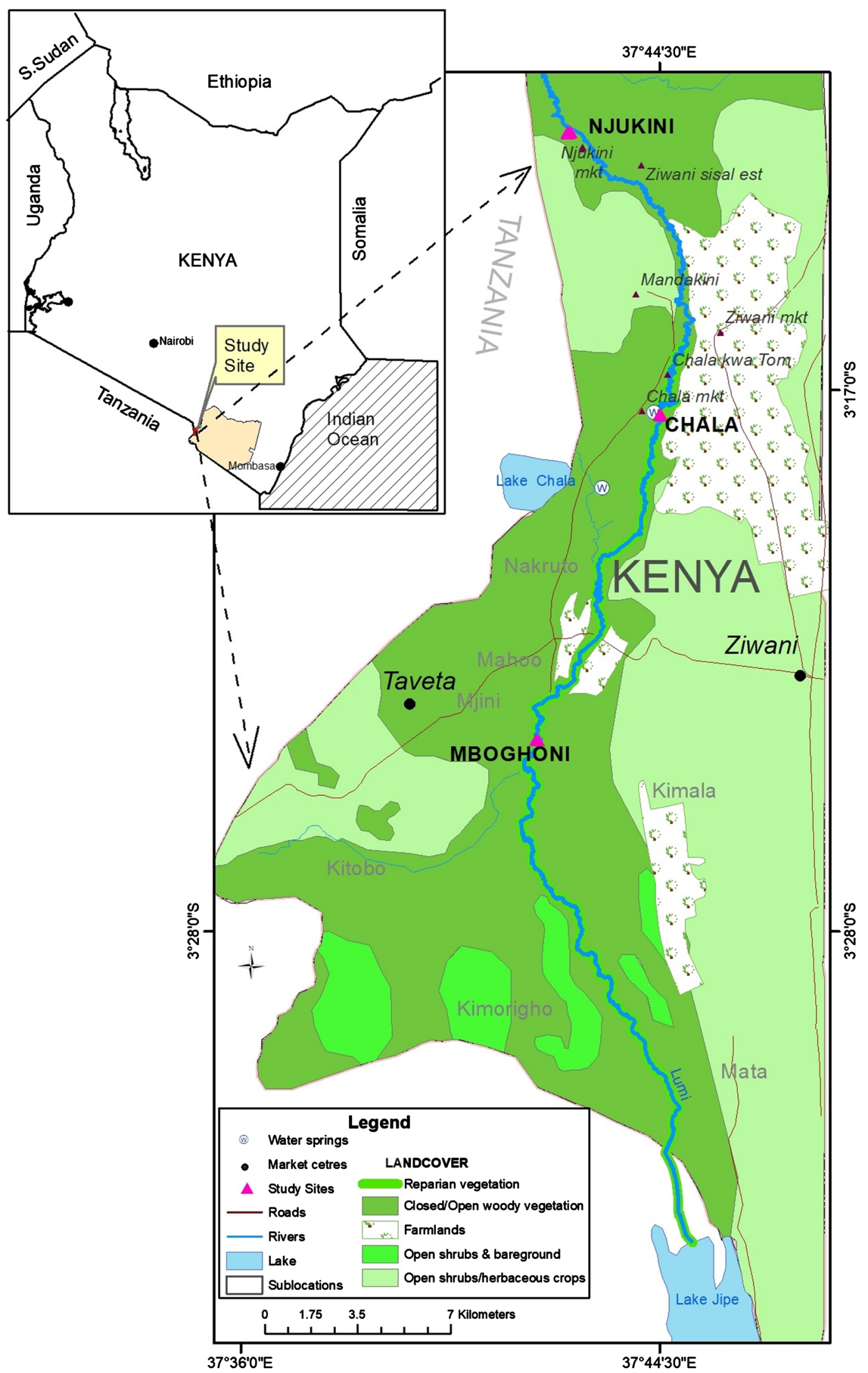

Figure 1. Location of study location in Taita Taveta County (Ndalilo et al., 2020). 
images had eight spectral bands with a spatial resolution of $30 \mathrm{~m}$ for bands $1-7$ and $15 \mathrm{~m}$ for band 8 which is a panchromatic band. The swath for ETM+ was $185 \times 185 \mathrm{~m}$. Landsat 8 Operational Land Imager (OLI) and Thermal Infrared Sensor (TIRS) images comprised of nine spectral bands with a spatial resolution of $30 \mathrm{~m}$ for bands $1-7$ and 9 . The resolution for band 8 (panchromatic) was 15 $\mathrm{m}$. The OLI and TIRS images had a swath of $185 \times 185 \mathrm{~m}$.

Geo-referencing which entailed assigning true ground coordinates to an image was done using permanent features detectable on the ground, while the orthorectification process was used to correct the pixel displacement caused by the topographical variations to ensure that every pixel is in its correct location regardless of elevation and viewing direction. A multi-date post-classification comparison change detection algorithm was used to determine changes in land cover in three intervals, 1987-2000, 2000-2010, and 2010-2019.

Selection of the time frame for analysis was based on the historical anthropogenic disturbances: the period between 1987 and 2000 was characterized with construction of irrigation canals and expansion of agricultural areas driven by increasing market prices; whereas the period between 2000 and 2010 was associated with artificial diversion of river course for dam construction, establishment of irrigation cannals and introduction of various conservation initiatives along River Lumi. The period between 2011 and 2019 was characterized with prolonged periods of drought which had a significant impact on land cover changes. These periods are characterized by different socio-economic and environmental factors that may have influenced land use and land cover changes differently thus providing a basis for comparative analysis.

\subsection{Socio-Economic Data}

Cross-sectional design was used to assess the impact of land use and land cover change on household livelihoods in River Lumi riparian ecosystem. Livelihood sources and household income levels were the independent variables influencing land cover change, the dependent variable. River Lumi riparian ecosystem was stratified in three main administrative locations namely Njukini, Chala and Mboghoni which are situated in the upper, middle and lower sections of the riparian ecosystem respectively. Simple random sampling was used to select households living in the three locations proportionate to the total number of households in each location. Unique codes were allocated to households living in three locations and the required number of households in each location randomly selected. A total of 353 household respondents were interviewed in the three locations.

Semi-structured questionnaires were administered to selected households to collect socio-economic data on the effect of land use and land cover change on household livelihoods. The key themes covered by the questionnaire included: land ownership and use, livelihood activities and their contribution to household incomes, and utilization of ecosystem goods and services. The questionnaire 
comprised of both close-ended and open-ended questions which help in clarifying reasons for responses, clearing up ambiguities, and exploring responses that fall outside the expected range of answers (Lazarsfeld, 1944). Likert scales were used to measure respondents' attitudes and perceptions on importance of River Lumi riparian ecosystem, changes in land use and land cover and implications on household livelihoods.

Prior to the data collection exercise, a pilot study was conducted in Nakuruto village which is located adjacent to Chala location, and does not form part of the study locations. The objective of the pilot study was to ascertain whether the proposed research methods and instruments were adequate and appropriate, and to help identify and address potential ambiguities and challenges that may occur while conducting the actual study. Data collected was analyzed for reliability by determining the Cronbach alpha reliability coefficient using Statistical Package for Social Sciences (SPSS) Version 21.0. Generally, a Cronbach's alpha of at least 0.70 is recommended as the best index for reliability (Borg \& Gall, 1989), hence the Cronbach alpha reliability coefficient of 0.72 obtained in the study ascertained the reliability of the data.

\subsection{Data Analysis}

Socio-economic data was analysed using SPSS version 21.0. One-way Analysis of Variance (ANOVA) was used to separate the means that were significantly different in relation to household income and amount of products extracted from the three locations within the riparian ecosystem. The F-test isolated significant effects associated with the independent variables at $95 \%$ confidence interval. Mean values and standard error of mean for household income and amount of products extracted from the three study locations within River Lumi riparian ecosystem were estimated using parametric models.

Landsat images were analysed using ArcGIS version 10.2 Software. For assessment of land use and land cover change, supervised classification was used to categorize the images into different land cover classes. River Lumi riparian ecosystem was categorized into six land cover classes: farmland, forest patches, grazing land, riverine vegetation, settlement and water body. Changes in land cover over the 32-year period between 1987 and 2019 were analysed for actual and periodic percentage change. Space-time substitution effect was analysed to ascertain which land use had changed fastest, and change detection maps highlighting the landscape transformations between 1987 and 2019 were generated. Tables and maps were used to illustrate the synthesized data obtained from the analysis of satellite imageries.

\section{Results}

\subsection{Trends in Land Cover Change in River Lumi Riparian Ecosystem}

Results of land cover changes in River Lumi riparian ecosystem between 1987 
and 2019 indicated that the area under farmlands, settlement and water body increased by $20.5 \%, 112.1 \%$ and $2.3 \%$ respectively while the area under forest patches, grazing land and riverine vegetation decreased by $52.7 \%, 3.0 \%$, and $36.6 \%$ respectively (Table 1 ).

Time-specific changes in land cover was analysed for three time frames: 19872000; 2000-2010; and 2010-2019. The area under farmland recorded the greatest increase (7.5\%) between 2010 and 2019, coinciding with the period when area under settlement recorded the highest increase of $34.7 \%$. During the same time, area under forest patches, grazing land and area under riverine vegetation recorded a decline of $30.0 \%, 2.0 \%$ and $16.7 \%$ respectively, reiterating the negative effects of increasing area under farmland and human settlement on the decline of both grazing land and riverine vegetation. The area under water body recorded mixed changes during the different time periods (Table 2).

The trends in land cover change between 1987 and 2019 in River Lumi riparian ecosystem using Landsat imageries based on six land use classes namely farmland, forest patches, grazing land, riverine vegetation and water body are shown in Figure 2.

\subsection{Effects of Land Use and Land Cover Change on Household Livelihoods}

The contribution of household livelihood sources to household income and the level of utilization of ecosystem goods and services by households living adjacent to River Lumi riparian ecosystem was assessed to ascertain the effects of land use and land cover change on household livelihoods.

\subsubsection{Main Livelihood Sources and their Contribution to Household Income}

The contribution of livelihood sources to household income (KES per annum; $100 \mathrm{KES}=1 \mathrm{USD}$ ) was assessed. Crop farming was the leading source of household income (KES. 170,183), followed by Business (KES. 150,256), Livestock production (KES. 146,291), and Casual labour (KES. 70,924). Results of the study indicated a tremendous increase in the area under crop production between 2011

Table 1. Land cover change in River Lumi riparian ecosystem between 1987 and 2019 using Landsat imageries.

\begin{tabular}{cccccc}
\hline \multirow{2}{*}{ Class Type } & \multicolumn{5}{c}{ Changes in land cover between 1987 and 2019} \\
\cline { 2 - 5 } & $\begin{array}{c}\text { Area in } \\
1987(\mathrm{ha})\end{array}$ & $\begin{array}{c}\text { Area in } \\
2019(\mathrm{ha})\end{array}$ & $\begin{array}{c}\text { Change } \\
(\mathrm{ha})\end{array}$ & $\begin{array}{c}\text { Change } \\
(\%)\end{array}$ & $\begin{array}{c}\text { Change type } \\
(-/+)\end{array}$ \\
\hline Farmland & 13,079 & 15,762 & 2683 & 20.5 & + \\
Forest patches & 4477 & 2116 & 2361 & 52.7 & - \\
Grazing land & 16,023 & 15,540 & 483 & 3.0 & - \\
Riverine vegetation & 1150 & 729 & 421 & 36.6 & - \\
Settlement & 513 & 1088 & 575 & 112.1 & + \\
Water body & 299 & 325 & 325 & 2.3 & + \\
\hline
\end{tabular}


Table 2. Comparison of land cover change of six land use classes in River Lumi riparian ecosystem between 1987 and 2019 using Landsat imageries; $(+)$ = Positive change, $(-)=$ Negative change and $(0)=$ No change

\begin{tabular}{|c|c|c|c|c|c|}
\hline Class type & Year & Area (ha) & $\begin{array}{c}\text { Change } \\
\text { (ha) }\end{array}$ & $\begin{array}{c}\text { Change } \\
(\%)\end{array}$ & $\begin{array}{l}\text { Type of } \\
\text { change }\end{array}$ \\
\hline \multirow{4}{*}{ Farmland } & 1987 & 13,079 & 0 & 0 & 0 \\
\hline & 2000 & 13,955 & 876 & 6.7 & + \\
\hline & 2010 & 14,660 & 705 & 5.1 & + \\
\hline & 2019 & 15,762 & 1102 & 7.5 & + \\
\hline \multirow{4}{*}{ Forest Patches } & 1987 & 4477 & 0 & 0 & 0 \\
\hline & 2000 & 4062 & 415 & 9.3 & - \\
\hline & 2010 & 3022 & 1040 & 25.6 & _ \\
\hline & 2019 & 2116 & 906 & 30.0 & _ \\
\hline \multirow{4}{*}{ Grazing land } & 1987 & 16,023 & 0 & 0 & 0 \\
\hline & 2000 & 15,706 & 317 & 2.0 & _ \\
\hline & 2010 & 15,851 & 145 & 0.9 & + \\
\hline & 2019 & 15,540 & 311 & 2.0 & _ \\
\hline \multirow{4}{*}{ Riverine Vegetation } & 1987 & 1150 & 0 & 0 & 0 \\
\hline & 2000 & 873 & 277 & 24.0 & _ \\
\hline & 2010 & 875 & 2 & 0.2 & + \\
\hline & 2019 & 729 & 146 & 16.7 & _ \\
\hline \multirow{4}{*}{ Settlement } & 1987 & 513 & 0 & 0 & 0 \\
\hline & 2000 & 620 & 107 & 20.9 & + \\
\hline & 2010 & 808 & 188 & 30.3 & + \\
\hline & 2019 & 1088 & 280 & 34.7 & + \\
\hline \multirow{4}{*}{ Water body } & 1987 & 299 & 0 & 0 & 0 \\
\hline & 2000 & 325 & 26 & 8.7 & + \\
\hline & 2010 & 325 & 0 & 0 & 0 \\
\hline & 2019 & 306 & 19 & 5.8 & - \\
\hline
\end{tabular}

and 2018 from an average of about 1.5 to 2.5 ha per household. The increase in area under crop production was attributed to the need to diversify crops grown in order to avert effects of climate change (39\%), increased demand for agricultural products in main towns in the Coast region such as Voi, Mombasa and Malindi (38\%), and competitive market prices for agricultural products (23\%). On the contrary, the average number of livestock kept by individual households reduced from 9 to 5 between 2011 and 2018. The number of immigrant livestock from neighbouring pastoralist communities mainly the Maasai as well as private ranches however increased, exerting additional pressure on River Lumi riparian ecosystem. 

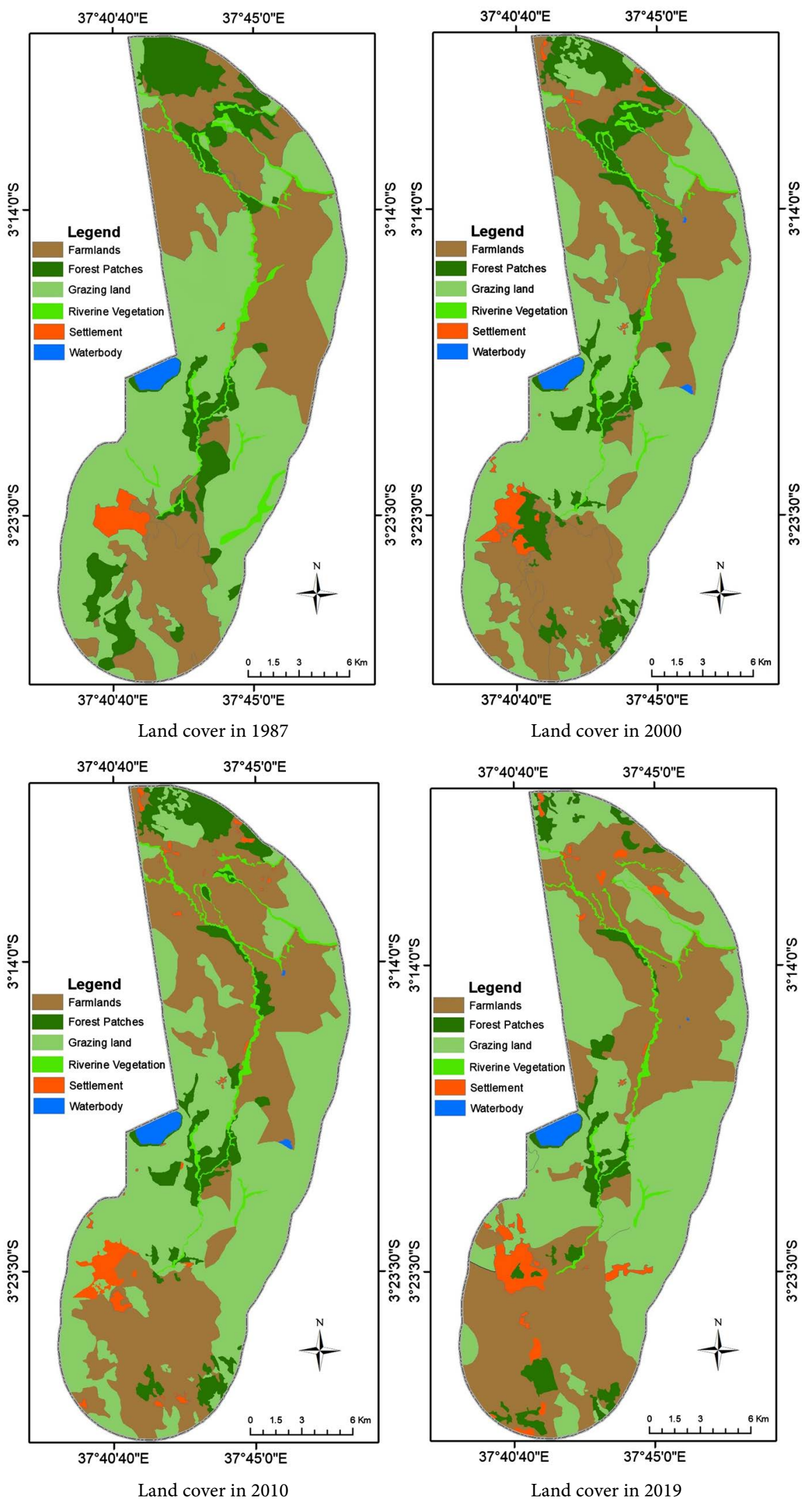

Figure 2. Land cover change between 1987 and 2019 in River Lumi Riparian ecosystem using Landsat imageries. 


\subsubsection{Utilization of Ecosystem Goods and Services by Households Living Adjacent to River Lumi Riparian Ecosystem}

Households living adjacent to River Lumi riparian ecosystem derive goods and services from the river and the adjacent riparian forest which significantly contribute towards sustaining their livelihoods. The main goods and services derived by households were water, thatching grass, poles and timber, herbal medicine, fodder, firewood and charcoal. A comparative analysis of level of extraction of ecosystem goods and services between 2011 and 2019 by households living adjacent to River Lumi riparian ecosystem revealed that the quantities of products extracted reduced significantly during the 8 -year period (Table 3).

Table 3. Quantity of products extracted per week by households living along River Lumi riparian ecosystem.

\begin{tabular}{cccc}
\hline \multirow{2}{*}{ Product extracted } & Unit of measurement & \multicolumn{2}{c}{ Year/quantity extracted per week } \\
\cline { 3 - 4 } & Litres & 2011 & 2019 \\
\hline Water & Bunch & 421 & 345 \\
Thatch grass & Pieces & 13 & 9 \\
Poles/Timber & Bunch & 33 & 21 \\
Herbal Medicine & Back load & 6 & 4 \\
Fodder & Head load & 19 & 8 \\
Firewood & Sack & 21 & 16 \\
Charcoal & 7 & 4 \\
\hline
\end{tabular}

\section{Discussion}

\subsection{Trends in Land Cover Change in River Lumi Riparian Ecosystem}

Analysis of changes in the area under farmlands, forest patches, grazing land, riverine vegetation, settlement and water body between 1987 and 2019 revealed varying trends. There was an increase in farmlands and settlement while forest patches, grazing land and riverine vegetation decreased. The increase in farmlands coincided with increase in population characterized by an overwhelming increase in area under settlement. These findings conform to the Kenya National Housing and Population Census report 2019, which indicated that Taveta SubCounty where River Lumi is located recorded a $34.8 \%$ increase in human population from 67,665 to 91,222 over the ten-year period between 2009 and 2019 (KNBS, 2019). The findings of this study also conform to those of similar studies conducted in riparian ecosystems in Kenya: Mutie et al. (2006) in Mara river basin; Baldyga et al. (2007) in River Njoro; Kathumo (2011) in river Gucha catchment; and Monene (2017) in Ngong river sub-catchment which indicated that forests, shrubland, grassland and water bodies have reduced at the expense of increase in agricultural land, settlement and urbanization. Population increase was noted to have resulted to encroachment of the riparian area for settlement and agricultural expansion, and increased exploitation pressure on the riparian 
forest and the adjacent river creating negative impacts on conservation of River Lumi riparian ecosystem. The decrease in forest patches and riverine vegetation were attributed to deforestation, over-exploitation of forest products and overgrazing brought about by influx of livestock from neighbouring communities and private ranches, while the decreasing area under grazing was attributed to expansion of farmlands in a bid to meet the growing demand for food. These findings compare with those of FAO (2016) which found out that small-scale agriculture is the most significant driver of deforestation in Africa, while the underlying factors affecting forest conversion include population growth, changing food consumption patterns, agricultural developments and poverty.

Analysis of trends in land cover change revealed that the area under farmland increased significantly between 1987 and 2019, with the greatest increase (7.5\%) occurring between 2010 and 2019. The period between 2000 and 2019 was characterized by an increase in population as confirmed by a sharp increase in settlement during that period. The area of forest patches recorded the highest decline (30.0\%) between 2010 and 2019 coinciding with the period when the area under settlement increased by $34.7 \%$. This is a pointer to deforestation and overexploitation of forest products due to population increase as well as encroachment of riparian land for settlement. Similarly, grazing land declined with the highest margin of $2.0 \%$ between 2010 and 2019. This decline was attributed to the increase in farmlands during the same period in a bid to meet the demand for food by the growing population. A similar trend was observed in the area under riverine vegetation which recorded the highest decline (16.7\%) between 2010 and 2019. Decline in riverine vegetation was attributed to encroachment of the riparian area by farmlands as well as overgrazing in the riparian area occasioned by influx of livestock from neighbouring Maasai pastoralist community and private ranches, and decline in grazing land. The area under settlement increased at an annual rate of 3.5\% between 1987 and 2019 recording an overall increase of $112.1 \%$. This trend was attributed to increase in population as confirmed by the Kenya National Housing and Population Census of 2019 (KNBS, 2019). The area under water body recorded the highest increase (8.7\%) between 1987 and 2000, followed by a decline of 5.8\% between 2000 and 2019. The period between 1987 and 2000 was marked with perennial floods partly occasioned by the Elnino rains (Opere, 2013) leading to the expansion of area under water body. The decline in area under water body between 2000 and 2019 coincided with increase in area under farmlands and was attributed to over-abstraction of water for crop irrigation exacerbated by perennial droughts which occurred during that period (Muli, 2014).

\subsection{Implications of Land Use and Land Cover Change on Household Livelihoods}

The main sources of livelihood among households living adjacent to River Lumi riparian ecosystem were crop farming and livestock production which were practiced by $84 \%$ and $70 \%$ of the households, respectively. The main crops grown 
were maize, bananas, tomatoes, onions, leafy vegetables, green grams and beans, while the main livestock kept were cattle, goats and sheep. Both crop farming and livestock production were mainly done for commercial purposes with the surplus produce used for subsistence. Results of the study showed that the area under crop production increased substantially in a period of seven years between 2011 and 2018 from an average of 1.5 ha to 2.5 ha per household. This is consistent with the Landsat images which established an increase of $7.5 \%$ in area under farmland from 705 ha to 1,102 ha between 2010 and 2019. The increase in area under crop production was mainly attributed to increased demand for agricultural products in main towns in the Coast region of Kenya such as Voi, Mombasa and Malindi, and competitive market prices for agricultural products. Consequently, crop farming was the leading source of income for households living adjacent to River Lumi riparian ecosystem, followed by business, livestock production and casual labour. Crop farming also contributed significantly to household food security. The main business undertaken by households living adjacent to River Lumi riparian ecosystem was trade in agricultural crops leading to relatively high income derived from business. Moreover, the strategic location of Taveta town at the border of Kenya and Tanzania coupled with an increase in human settlement as indicated by Landsat images makes the area a major business hub. Casual labour was mainly employed on farmlands to support both crop and livestock production.

It was established from Landsat images that grazing land decreased by $3 \%$ between 1987 and 2019 from 16,023 to 15,540 ha. The decline in grazing land was attributed to encroachment of grazing areas for crop farming. Consequently, the numbers of livestock kept by households living adjacent to River Lumi have declined over time leading to decline in associated benefits derived from livestock keeping mainly food and income. On the contrary, there has been an influx of livestock from private ranches and neighbouring pastoralist communities which have contributed immensely to degradation of the riparian area resulting from overgrazing and livestock trampling. Analysis of Landsat images also revealed a decline in forest patches and riverine vegetation by $52.7 \%$ and $36.6 \%$ respectively between 1987 and 2019. The conversion of riverine vegetation and forest patches to agricultural land through both crop and livestock production has contributed to dwindling surface water resources with negative impacts on community livelihoods which are largely dependent on the river and the adjacent riparian forest (Muli, 2014; Ngugi et al., 2015). The diversion of water from the river for irrigation has further contributed to the decline of water levels in the river with profound effects on biodiversity which support household livelihoods through provision of ecosystem goods and services. Moreover, the high usage of chemical fertilizers, pesticides, fungicides and herbicides in adjacent farmlands has resulted in water pollution with potential negative impacts on human health (Muli, 2014).

Results of the socio-economic survey revealed that the amount of ecosystem 
goods and services extracted by households namely water, thatching grass, poles and timber, herbal medicine, fodder, firewood and charcoal declined significantly between 2011 and 2019. An overwhelming increase in area under settlement by $112.1 \%$ along River Lumi riparian ecosystem during the 32-year period between 1987 and 2019 resulted in over-exploitation of riparian forest resources for extraction of construction materials and fuelwood, as well as charcoal production leading to degradation of the riparian ecosystem. Degradation of the riparian ecosystem is inextricably tied to decrease in ecosystem goods and services derived from the riparian ecosystem over the years with significant negative impacts on livelihoods. Previous studies have established that over-exploitation of forest resources through illegal logging and charcoal production results to forest degradation, with the potential for a vicious cycle between poverty and environmental degradation (Ruuska, 2012). Similarly, other studies (Ngoye \& Machiwa, 2004; Chiwa, 2012; Nzunda et al., 2013) have established that some of the main causes of land use and land cover change in riparian ecosystems are unsustainable rates of resource exploitation, poverty and high population growth rates which have fuelled demand for food, non-food agricultural products and energy.

\section{Conclusion and Recommendation}

River Lumi riparian ecosystem experienced rapid and extensive land use changes over the 32-year period between 1987 and 2019. The increase in population in surrounding areas coupled with encroachment of the riparian area for crop farming and livestock grazing resulted to loss of riparian forest patches/ vegetation and associated biodiversity. The resulting degradation poses significant threats to River Lumi with dire consequences on local livelihoods and ecological processes supported by the river and adjacent riparian ecosystem. The study revealed that the area under farmlands and settlement increased while area under forest patches, grazing land and riverine vegetation decreased between 1987 and 2019. The annual increase in crop area coupled with an annual loss of riparian forest area and riverine vegetation is likely to contribute further to the degradation of River Lumi riparian ecosystem resulting to loss of ecosystem services and the associated contribution to household wellbeing and biodiversity. This is further exacerbated by the overwhelming increase in human population by $112.1 \%$ over the 32-year period which exerts additional exploitation pressure on the riparian ecosystem. Development of a land use plan for River Lumi riparian ecosystem that clearly delineates settlement zones, conservation areas and agricultural production zones should be undertaken to prevent encroachment of riparian area for other land uses. This will ensure sustainable management of the riparian ecosystem.

\section{Acknowledgements}

The authors acknowledge the financial and logistical support from Kenya Fore- 
stry Research Institute and RUFORUM through the TAGDev Programme of Egerton University. The input of Mr. Geoffrey Maina in Landsat image processing, as well as the willingness of individual households in providing useful information used in the preparation of this paper is highly appreciated.

\section{Conflicts of Interest}

The authors declare no conflicts of interest regarding the publication of this paper.

\section{References}

Baldyga, T. J., Miller, S. N., Maina G. C., \& Shivoga, W. (2007). Suitability of the Automated Geospatial Watershed Assessment (AGWA) Tool in Assessing Hydrological Response and Land Cover Change in River Njoro Watershed, Kenya. Egerton Journal of Science and Technology, 7, 56-71.

Borg, W. R., \& Gall, M. D. (1989). Educational Research: An Introduction (5th ed.). New York: Longman.

Chiwa, R. (2012). Effects of Land Use and Land Cover Changes on the Hydrology of Weruweru-Kiladeda Sub-Catchment in Pangani River Basin, Tanzania. PhD Thesis, Nairobi: Kenyatta University.

DeFries, R. J., Foley, J. A., \& Asner, G. P. (2004). Land Use Choices: Balancing Human Needs and Ecosystem Function. Frontiers in Ecology and the Environment, 2, 249-257. https://doi.org/10.1890/1540-9295(2004)002[0249:LCBHNA]2.0.CO;2

FAO (2016). State of the World's Forests 2016. Forests and Agriculture: Land-Use Challenges and Opportunities. Rome.

Faye, L. C. (2016). Impacts of Community-Forest Management on Land Use Change, Vegetation Dynamics and Carbon Stocks in South-Eastern Senegal. PhD Thesis, Kabwe: Kwame Nkrumah University of Science and Technology.

Foley, J. A., Ramankutty, N., \& Brauman, K. (2011). Solutions for a Cultivated Planet. Nature, 478, 337-342. https://doi.org/10.1038/nature10452

Halmy, M. W. A., Gessler, P. E., Hicke, J. A., \& Salem, B. B. (2015). Land Use and Land Cover Change Detection and Prediction in the North-Western Coastal Desert of Egypt Using Markov-CA. Applied Geography, 63, 101-112.

https://doi.org/10.1016/j.apgeog.2015.06.015

Houghton, R. A. (1994). Global Impact of Land-Cover Change. BioScience, 44, 305-313. https://doi.org/10.2307/1312380

Kadeba, A., Nacoulma, B. M. I., Ouedraogo, A., Bachmann, Y., Thiombiano, A., Schmidt, M., \& Boussim, J. I. (2015). Land Cover Change and Plants Diversity in the Sahel: A Case Study from Northern Burkina Faso. Annals of Forest Research, 58, 109-123. https://doi.org/10.15287/afr.2015.350

Kathumo, V. M. (2011). Application of Remote Sensing and GIS in Assessing Land Use Cover and Land Use Changes and Their Impact on Hydrological Regime in River Gucha Catchment, Kenya. PhD Thesis, Unpublished.

Kindu, M., Schneider, T., Teketay, D., \& Knoke, T. (2015). Drivers of Land Use/Land Cover Changes in Munessa-Shashemene Landscape of the South-Central Highlands of Ethiopia. Environmental Monitoring Assessment, 187, 452.

https://doi.org/10.1007/s10661-015-4671-7

KNBS Kenya National Bureau of Statistics (2019). Kenya Population and Housing Census 
Volume 1: Population by County and Sub-County. Government of Kenya.

Lazarsfeld, P. F. (1944). The Controversy over Detailed Interviews-An Offer for Negotiation. Public Opinion Quarterly, 8, 38-60. https://doi.org/10.1086/265666

Mendez-Estrella, R., Romo-Leon, J. R., Castellanos, A. E., Gandarilla-Aizpuro, F. J., \& Kyle Hartfield, K. (2016). Analyzing Landscape Trends on Agriculture, Introduced Exotic Grasslands and Riparian Ecosystems in Arid Regions of Mexico. Remote Sensing, 8, 664. https://doi.org/10.3390/rs8080664

Monene, A. K. (2017). Effects of Watershed Land Use Change on Streamflow of Motoine/ Ngong River, Nairobi River Basin, Kenya. Mathematics and Physical Sciences Research, 5, 113-120.

Muli, J. M. (2014). The Impact of Irrigated Agriculture in Dry Lands on the Natural Environment: A Case Study of Chala Ward in Taita Taveta County, Kenya. Msc Thesis, Nairobi: University of Nairobi.

Mutie S. M., Home, P., Gadain, H., Mati, B., \& Gathenya, J. (2006). Evaluating Land Use Change Effects on River Flow Using USGS Geospatial Streamflow Model in Mara River Basin, Kenya. Bonn: Center for Remote Sensing of Land Surfaces.

Nacoulma, B. M. I., Schumann, K., Traoré, S., Marcus, B. R., Karen, H., Rudiger, W., \& Thiombiano, A. (2011). Impacts of Land-Use on West Africa Savanna Vegetation: A Comparison between Protected and Communal Area in Burkina Faso. Biodiversity and Conservation, 3, 62-72.

National Environment Management Authority (NEMA) (2009). Lake Jipe Basin Integrated Management Plan 2009-2014.

Ndalilo, L. A., Kirui, B. K., \& Maranga, E. K. (2020). Socio-Economic Drivers of Degradation and Their Implication on Conservation of River Lumi Riparian Ecosystem in Kenya. Open Journal of Forestry, 10, 307-319. https://doi.org/10.4236/ojf.2020.103020

Ngoye, E., \& Machiwa, J. F. (2004). The Influence of Land-Use Patterns in the Ruvu River Watershed on WATER quality in the River System. Physics and Chemistry of the Earth, 29, 1161-1166. https://doi.org/10.1016/j.pce.2004.09.002

Ngugi, K., Ogindo, H., \& Ertsen, M. (2015). Impact of Land Use Change on Hydrology of Mt. Kilimanjaro: The Case of Lake Jipe Catchment. Geographical Research Abstracts, $17,2015-4526$.

Nzunda, N. G., Munishi, P. P. T., Soka, G. E., \& Monjare, J. F. (2013). Influence of SocioEconomic Factors on Land Use and Vegetation Cover Change in and around Kagoma Forest Reserve in Tanzania. Ethiopian Journal of Environmental Studies and Management, 6, 480-488. https://doi.org/10.4314/ejesm.v6i5.5

Odira, P. M. A., Nyadawa, M. O., Okelloh, N., Juma, N. A., \& Obiero, J. P. (2010). Nile Basin. Water Science \& Engineering, 3, 64-78.

Opere, A. (2013). Floods in Kenya. In Developments in Earth Surface Processes (Vol. 16, pp. 315-330). Amsterdam: Elsevier.

https://doi.org/10.1016/B978-0-444-59559-1.00021-9

Republic of Kenya (2014). Taita Taveta County Integrated Development Plan 2013-2017. Nairobi: Government Printers.

Rodriguez, L. C., Pascual, U., Muradian, R., Pazmino, N., \& Whitten, S. (2011). Towards a Unified Scheme for Environmental and Social Protection: Learning from PES and CCT Experiences in Developing Countries. Ecological Economics, 70, 2163-2174. https://doi.org/10.1016/j.ecolecon.2011.06.019

Ruuska, E. (2012). The Significance and Sustainability of Charcoal Production in the Changing Landscape of Dakatcha Woodland, SE Kenya. Master's Thesis, Helsinki: 
University of Helsinki.

Wang, S., Wu, B., \& Yang, P. (2014). Assessing the Changes in Land Use and Ecosystem Services in an Oasis Agricultural Region of Yanqi Basin, Northwest China. Environmental Monitoring Assessment, 186, 8343-8357.

https://doi.org/10.1007/s10661-014-4009-x

Williams, M. (1994). Forests and Tree Cover. In W. B. Meyer, \& B. L. Turner (Eds.), Changes in Land Use and Land Cover: A Global Perspective (pp. 97-124). Cambridge: Cambridge University Press.

World Bank (1992). World Development Report 1992: Development and the Environment. Washington DC: The World Bank. https://doi.org/10.2307/1973669 